\title{
The Effect Of Auditor Independence On International Capital Markets For eCommerce Firms
}

Thomas J. Tribunella, (E-mail: ftjt@ sunyit.edu), State University of NY Institute of Technology Heidi R. Tribunella, (E-mail: heiditribunella@ prodigy.net), Utica School of Commerce

\begin{abstract}
According to the efficient market hypothesis, the market for securities can be described as efficient if the market reflects all available information and reacts quickly to new information (Schroeder and Clark 1998). Investors depend on financial statements to help them judge opportunities, risks, and investment alternatives (Revsine, Collins and Johnson 1999). This information must be verified by independent sources such as auditors. The relationship between auditor and stockholder is based on agency theory (Schroeder and Clark 1998), where the agent (auditor) has a fiduciary relationship with the principle (stockholders). Any loss of faith in auditor independence by investors will seriously affect the information value of financial statements.
\end{abstract}

Auditor independence rules must be easy to understand and rigorously enforced or the public's confidence in financial statements will erode. This paper will specifically assess the difficulties encountered by large accounting firms such as PriceWaterhouseCoopers (PWC) and Arthur Andersen in their efforts to remain independent with respect to their e-commerce clients. Many ecommerce companies have innovative and untested business models as well as inexperienced and untraditional business managers. Some auditors fail to measure the risk associated with these intangible, knowledge-based attributes. In addition, auditor independence may be blurred by the promise of lucrative consulting contracts. According to Arthur Levitt, the Chair of the SEC in 1999:

“The dynamic nature of today's capital markets creates issues that increasingly move beyond the bright line of black and white. New industries, spurred by new services and new technologies, are creating new questions and challenges that must be addressed. Today, we are witnessing a broad shift from an industrial economy to a more service based one; a shift from bricks and mortar to technology and knowledge." (Levitt 1999)

The objective of this paper is to review current independence rules, assess the difficulty in maintaining independence in the current e-commerce environment, and to make suggestions for improving independence rules. In addition, investigations conducted by the Securities and Exchange Commission (SEC) and new legislation such as the Sarbanes-Oxley Act will be reviewed as possible solutions to the problem.

\section{Introduction}

ndependence is the most important factor in giving an auditor's opinion on the financial statement's credibility. To be independent, an auditor must be independent in fact and independent in appearance. Independence in fact is achieved when an auditor maintains an unbiased view during the entire audit.

Readers with comments or questions are encouraged to contact the authors via email. 
Independence in appearance is achieved when the users of the audit report view the auditor as independent (Arens and Loebbecke, 1988).

Direct and indirect financial interests may impair auditor independence. An example of a direct financial interest occurs when an auditor owns stock in the company he or she is auditing. Direct financial interests always impair independence. An indirect interest may impair independence if it is material to the auditor's net worth. Independence can also be impaired by the financial interest and business relationships of the auditor's close family relatives (Whittington and Pany 1998). When management hires and compensates the auditors there is an inherent conflict of interest. In the case of e-commerce companies, the same accounting firm usually performs audit, tax, and expensive consulting work in the area of information systems.

With the fast paced e-commerce activities of the current period, an auditor's relationship with managers can affect his independence. In addition, as more money is invested in consulting and information systems, compliance with independence rulings become increasingly more difficult to adhere to. This appeared to be the case for Andersen and PriceWaterhouseCoopers, both firms are specifically examined in this paper. In addition, this paper will look at independence rules, the difficulty in maintaining independence in today's fast paced e-commerce environment, and the related effect on capital markets.

\section{2. eCommerce Risk And International Markets}

Digital products may be costly to create but inexpensive to reproduce, as a result, an e-commerce firm may have large upfront fixed costs, but can deliver services and digital products at a low variable cost per unit. Accordingly, e-commerce companies may not book profits for the first few years of operation. These special circumstances will increase business risk and audit risk. Business risk is the risk that the business will fail to continue as a going concern due to lack of profits and cash flow. Audit risk is the risk that the auditor will issue an incorrect opinion on the financial statements. Generally, audit risk increases as business risk increases. An independent point of view can play a key role in assessing certain business and audit risks when auditors and investors are faced with new economy investments and volatile economic conditions. This paper will look at the problems encountered with independence and its importance for maintaining efficient international capital markets.

In addition, traditional companies are making larger investments in market branding, networking, Web site construction, and database systems. The Financial Accounting Standards Board (FASB) and International Accounting Standards Committee (IASC) have both recognized this trend. These investments can be categorized in four stages as follows (see Exhibit 1):

Exhibit 1: Stages of eCommerce Implementation

\begin{tabular}{|c|c|c|}
\hline eCommerce Stage & Full eCommerce Firms & Hybrid Firm - Bricks and Clicks \\
\hline $\mathbf{1}$ & Brochure Ware & $\begin{array}{c}\text { Paper-based and Physical Marketing Combined with } \\
\text { Electronic Brochures and Internet Marketing }\end{array}$ \\
\hline 3: Business to & Order Entry & $\begin{array}{c}\text { Face-to-face and Electronic Order Entry at Web Site's Customer } \\
\text { Interface }\end{array}$ \\
Customer (B2C) & $\begin{array}{c}\text { Intranet and Accounting } \\
\text { Information Systems (AIS) }\end{array}$ & $\begin{array}{c}\text { Manual and Electronic Integration of Web Site, } \\
\text { Front Office, and Back Office Functions }\end{array}$ \\
\hline 4: Business to \\
Business (B2B) & $\begin{array}{c}\text { Extranet and Enterprise Resource } \\
\text { Planning (ERP) Systems }\end{array}$ & $\begin{array}{c}\text { Manual and Electronic Integration of Supply Chains and Value } \\
\text { Chains }\end{array}$ \\
\hline
\end{tabular}

Many traditional companies are now hybrid firms and have been able to enhance their business models with e-commerce applications. Pure e-commerce start-up firms experienced an excellent beginning just a few years ago only to fall onto hard times. The Internet boom and bust that occurred from 1996 to 2002 was one of the most important business phenomena's of the past several decades. In the wake of this historic period, accountants, investors, analysts, and business managers have an unprecedented opportunity to learn from past mistakes and successes. 
The dot-com bear market may indicate the end of the gold rush stage for technology firms. Down $39.3 \%$ in 2000, NASDAQ suffered the largest one-year loss in its 30-year history. In 2001, the NASDAQ continued its downward trend with a $21.1 \%$ loss. The statistics in Exhibit 2, compiled by Webmergers.com, report the shutdowns and bankruptcies of substantial Internet companies that have received significant funding.

\section{Exhibit 2: Dot-Com Shutdowns of Substantial Net Companies By Quarter}

\begin{tabular}{|l|c|}
\hline \multicolumn{1}{|c|}{ Month } & Number \\
\hline March 2000 & 5 \\
\hline June 2000 & 31 \\
\hline September 2000 & 52 \\
\hline December 2000 & 135 \\
\hline March 2001 & 164 \\
\hline June 2001 & 181 \\
\hline September 2001 & 119 \\
\hline December 2001 & 80 \\
\hline March 2002 & 54 \\
\hline June 2002 & 39 \\
\hline
\end{tabular}

Source: Webmergers.com
Inexperienced stockholders may have unrealistic expectations and disgruntled investors who lost money during the Internet shakeout are taking legal actions against Wall Street investment firms. In the wake of the major bankruptcies such as Enron, WorldCom, Adelphia Communications, and Global Crossing, lawsuits will surely effect the accounting profession if auditors fail to remain independent before, during, and after audit engagements. Auditors must consider the high failure rate of innovation and technology applications when they assess audit risk and business risk. Only an independent point of view can help auditors assess going concern issues and reduce potential liability exposure.

According to the Efficient Market Hypothesis a stock's current market price reflects the knowledge and expectations of investors (Revsine, Collins and Johnson 1999). Investors receive a material portion of their knowledge about a stock from financial statement information such as profits. In volatile and risky industries such as ecommerce independent auditors can add value to financial information. The quality of earnings is an important factor in forming investor expectations (see Exhibit 3).

\section{Exhibit 3: The Efficient Market Hypothesis}

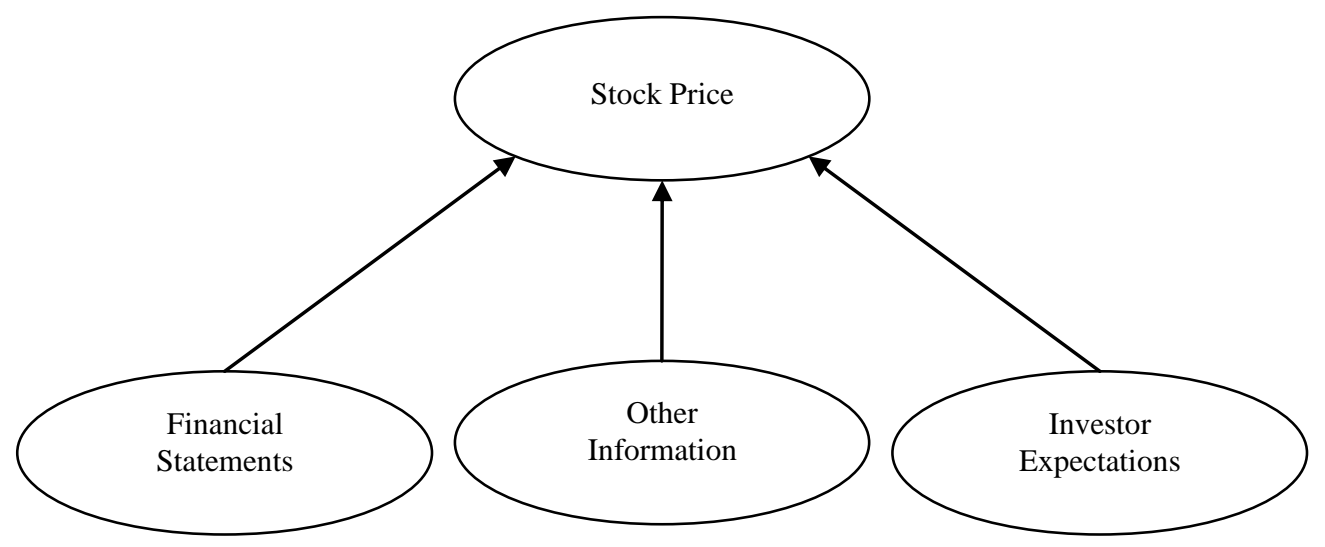

High-tech organizations, such as e-commerce entities, have many distinctive attributes that justify an enhanced approach to auditing and auditor independence. For example, Internet ventures are free of the time and place restrictions that inhibit market penetration and create an international reach. In addition, stock options granted to ecommerce officers create an incentive to manage earnings. Since e-commerce firms operate globally, auditors must consider the difficulty of tracking investments, liabilities, and revenues across many boarders and cultures. Moreover, e-commerce firms can raise capital and allocate resources in a wide variety of countries from the point of startup. This is a relatively new phenomenon in the history of capitalism. Twenty years ago small companies would not consider world markets during the start-up stage. However, with the advent of e-commerce, global reach becomes a basic component of even a small company's business model. 


\section{American And International Rules On Auditor Independence}

Auditor independence is critical to an efficient capital market. Investors allocate resources to capital markets based upon the financial information they receive. The information's validity is ensured by the independence of auditors. If there is a problem with the financial information, independent auditors report such problems and if a serious problem exists, auditors appropriately modify their opinion (Walker 1999). Auditors express an opinion on financial statement to fulfill their fiduciary responsibilities to the directors and shareholders of the company. The graphic in Exhibit 4 maps the relationships between stockholders, directors, management and auditors based on agency theory, which is also called contract theory (Wolk, Tearney and Dodd 2001).

Exhibit 4: Agency Theory in Auditing

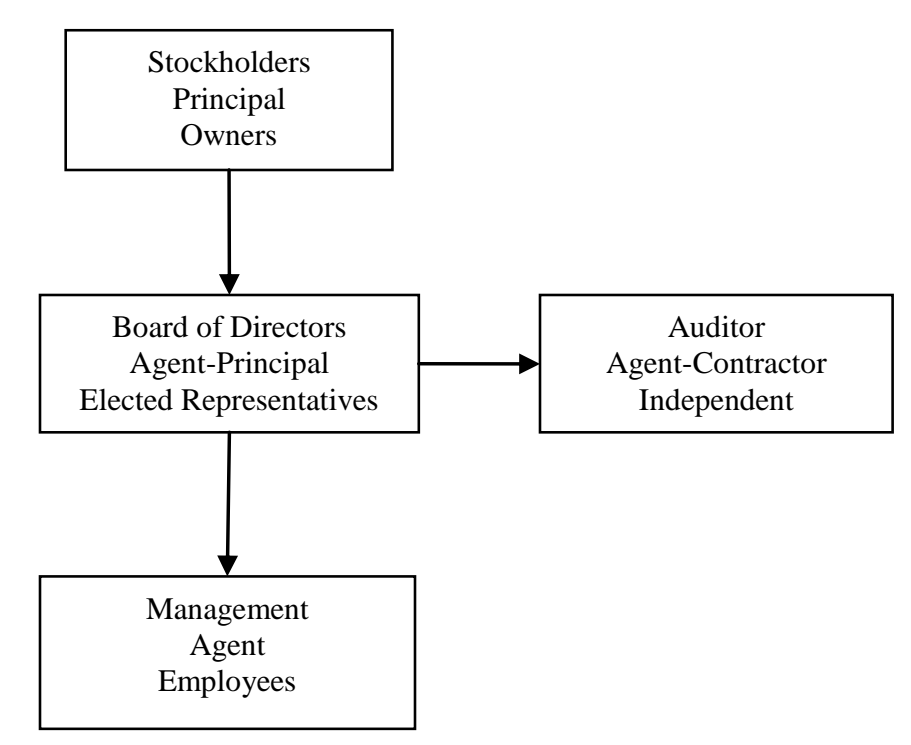

Given the current accounting scandals, auditors have not been maintaining independence. A number of issues are causing independence violations. PWC was fined by the SEC (Securities and Exchange Commission) for independence violations that were related to various direct and indirect financial interests. In addition to investment independence violations, auditors are having difficulty maintaining objectivity due to large audit and consulting fee arrangements. In the Enron case, Andersen received \$55 million in fees. It was argued that this amount was inmaterial to Andersen's annual revenue on a nation-wide basis however the amount was surely material to the Houston office that conducted the audit. In addition, some firms may have in-material audit fees, but derive a large amount of consulting revenues from audit clients. Maintaining independence in the current business environment is a challenge. Independence is critical to maintaining the public's confidence in financial information. When the public's confidence is eroded, the capital markets respond negatively.

Independence rulings do not apply to all services provided by accountants. Independence is not required for management consulting services, tax services, or accounting services. Independence rules do apply to audits, reviews of financial statements, attestation services, examinations of financial forecasts, and the application of agreed-upon procedures to information. The independence rules that are currently followed were written in a very different economic era. Most independent rules were made when accountants did not perform consulting and tax services. Most services offered at the time were accounting and audit services. Independence in mental attitude is absolutely necessary when performing attestation procedures in order to gain public confidence in the auditor's opinion. Without such confidence, the marketability of the auditor's attestation services would be greatly reduced (Goldwasser 1999). 
Rule 101 of the American Institute of Certified Public Accountants (AICPA) governs the independence of public accountants. Rule 101 states that CPAs should not express an opinion on the financial statements of a company unless he or she is independent with respect to the entity on which the CPA is expressing an opinion. Rule 101 then gives examples of items that would impair a CPA's independence. The following items impair independence as listed in Rule 101:

- $\quad$ A direct or material indirect financial interest.

- $\quad$ Any joint closely held business investment with the company, officer, director, or principal stockholder.

- Loans with the company, officer, director or principal stockholder, with the exception of immaterial loans, home mortgages or other secured loans.

- A connection with the company as a promoter, underwriter, voting trustee, a director or officer or as any capacity as management.

- $\quad$ Trustee for the pension or profit-sharing plan of the company.

Interpretation 101 defines in greater detail the rules of independence. Interpretation 101 applies to three categories of CPA's and their staff:

1. All partners in the firm.

2. All managerial employees assigned to an office that significantly participates in the engagement.

3. All professional staff personally participating in the engagement.

If an employee's independence is impaired and that employee is not functioning as a manager, then the employee can just be assigned to other engagements without impairing the independence of the firm (Whittington and Pany 1998).

A direct financial interest is a direct ownership of stock or other equity shares by the auditor and the auditor's immediate family. The immediate family is the auditor's spouse and his or her dependents. If a spouse or dependent owns a share of stock, it is the same as the auditor owning the share of stock in the determination of independence. Independence rules differ for close relatives than those for the immediate family. Close relatives are defined as parents, grandparents, parents-in-law, brothers, sisters, non-dependent children, grandchildren, and their respective spouses. The auditor cannot participate in the audit of a company if a close relative has a material interest in the client that the auditor is aware of, or is employed by the client in a significant influence position or an audit sensitive position. For instance, an auditor's brother in-law could work as a production worker for GM (General Motors) without impairing the auditor's independence. However, if this brother in-law was a controller or worked in the accounting department, the auditor's independence would be impaired. Other relatives do not impair independence unless the auditor has close personal and financial ties with that relative (Whittington \& Pany 1998).

Other situations that may impair independence are unpaid client fees, litigation with the client, or past employment with the client. If fees are still owed to the auditor by the client, his independence is impaired because he is now a creditor of the client. All audit fees must be paid prior to the beginning of fieldwork of the next audit. If an auditor is in litigation with his client, he obviously would not be able to maintain and independence in mental attitude. If an auditor has worked for the client in an audit sensitive position, he cannot serve on the audit if the audit covers the period the auditor worked for the client. Otherwise, he would be auditing his own work (Whittington and Pany 1998). Below is a list of auditor responsibilities to the investors:

- $\quad$ The auditors check financial statement for investors.

- $\quad$ They work for the investors; they do not work for management.

- $\quad$ The job of an auditor is to be skeptical.

- $\quad$ Auditors should probe and search for violations of accounting rules.

- $\quad$ The auditors should not become close associates with the management.

- $\quad$ Stock market investors depend on reliable financial information to make investment decisions.

- $\quad$ Auditors are supposed to be the guardians of the quality of financial information. 
A study was conducted by Chi-Wen Jevons Lee and Zhaoyang Gu that examined low-balling, legal liability, and auditor independence. Low-balling is when an audit firm offers an extremely low fee in the first few years of a long-term audit contract to "steal" a client from another firm. The study was very interesting as it contradicted the SEC's view on low-balling. The SEC believes that low-balling can lead to decreased auditor independence. The study showed that it could actually increase auditor independence. The difference in the arguments of the SEC and the study is who controls the right to hire and fire the auditors. If the owner hires the auditors, then independence is enhanced. If management hires the auditors then independence can be decreased. In reality, there is a blending of owner and management hiring of auditors. If owners have some involvement in the choice of auditors, then low balling can "enhance the efficiency" of the process (Lee and Gu 1998).

It should be noted that there is a difference in the independence rules of the American Institute of Certified Public Accountants (AICPA) and the Securities \& Exchange Commission (SEC). The SEC specifically disallows the auditor to post the general ledger, make closing entries, and maintain subsidiary records for audit clients registered with the SEC. The AICPA does not place such limitations on independence rules (Whittington and Pany 1998). The SEC has recognized a need to review the current independence rules and has established the Independence Standards Board (ISB). The ISB was created to address independence issues as auditors engage in new service areas, merge, become more like business partners with clients and evolve in their professional relationships. The ISB is a private sector body that has worked to develop a conceptual framework for independence rules, to establish independence rules, and to interpret such rulings (Stevens 1997).

Independence Rules for the Institute of Chartered Accountants (ICA) are different in form but similar in substance to the AICPA rules. The ICA of Ontario, Canada specifically states: "A member who engages to perform an assurance or specified auditing procedures engagement shall be and remain free of any influence, interest or relationship, in respect of his or her client's affairs, which impairs the member's professional judgment or objectivity or which, in the view of a reasonable observer, would impair the member's professional judgment or objectivity."

Since they all maintain their own jurisdictions, each province in Canada and the ICA of England and Wales have slightly different rules of professional conduct. However, they all base their code of conduct on the same underlying spirit of ethical principles. All Chartered Accountants (CA) are required to act with integrity, objectivity, and a commitment to excellence and the public interest.

With the spread of e-commerce the internationalization of capital markets will continue. Accordingly, multination auditing standards are needed. Even though auditing standards are determined on a country-by-country basis there is a movement to standardize the rules on a worldwide basis. The International Federation of Accountants (IFAC) is a worldwide organization consisting of 80 national organizations such as the AICPA and the ICA of England and Wales. The IFAC has formed the International Auditing Practices Committee (IAPC). The IAPC issues International Standards on Auditing. These standards seek to eliminate material inconsistencies between national auditing standards (Whittington and Pany 1998). The IAPC is in a relatively early stage of development but its standards will receive more attention as capital market become more international through the global reach of ecommerce.

\section{Case Study: PriceWaterhouseCoopers}

When Price Waterhouse merged with Coopers \& Lybrand, one of the world's largest accounting firms was created. PriceWaterhouseCoopers (PWC) is a global company with offices in every area of the world. As a result, PWC influences the quality of financial information on a worldwide basis because it controls such a large market share. In 1997 an investigation was conducted at the Tampa office of Coopers \& Lybrand (C\&L). This investigation found that three individuals had owned securities in clients that they audited. It also found that the C\&L retirement plan owned securities in publicly held audits. As a result of this investigation and the merger with Price Waterhouse, the Securities and Exchange Commission ordered PriceWaterhouseCoopers to conduct an internal investigation that would be supervised by an "independent counsel." The SEC chose Lankler, Siffert \& Wohl, LLP from New York City to be the independent counsel (Fardella, Hollander-Blumoff, Fleisher, Fukuyama and Klosterman 2000). 
Because of the order, PWC took on a confirmation process to assess independence violations. These confirmations required professional staff working for PWC to confirm any independence violations or suspected violations they may have had over a specific time period. These confirmations were then entered into a database. From this database, the firm of Lankler, Siffert \& Wohl, LLP, made selections to substantiate violations and reported matters. The confirmation process showed 9,889 reported matters of which 8,064 were determined to be independence violations (see Exhibit 5). This is a significant number for only 36,170 respondents (Fardella, Hollander-Blumoff, Fleisher, Fukuyama and Klosterman 2000).

Exhibit 5: Reported Violations by Source of Violation

\begin{tabular}{|l|c|c|}
\hline Violation & $\begin{array}{c}\text { Number of } \\
\text { Reported Violations }\end{array}$ & $\begin{array}{c}\text { Percent of } \\
\text { Reported Violations }\end{array}$ \\
\hline A. Direct Investment by the Reporter & 2,960 & $36.7 \%$ \\
\hline B. Spouse/Cohabitant Direct Investment & 904 & $11.2 \%$ \\
\hline C. 104(k) - Former Employer (Reporter) & 224 & $2.8 \%$ \\
\hline D. Spouse/Cohabitant - 401(k) - Current Employer & 214 & $2.7 \%$ \\
\hline E. Spouse/Cohabitant 401(k) - Former Employer & 128 & $1.6 \%$ \\
\hline F. IRA (Reporter) & 727 & $9.0 \%$ \\
\hline G. Spouse/Cohabitant IRA & 556 & $6.9 \%$ \\
\hline H. Dependent Investment & 658 & $8.2 \%$ \\
\hline I. Non-Dependent Close Relative Investment & 76 & $0.9 \%$ \\
\hline J. Family Member's Employment & 19 & $0.2 \%$ \\
\hline K. Gift/Inheritance & 147 & $1.8 \%$ \\
\hline L. Executor/Trustee & 331 & $4.1 \%$ \\
\hline M. Beneficiary & 22 & $0.3 \%$ \\
\hline N. Broker/Dealer Cash/Securities Account & 423 & $5.2 \%$ \\
\hline O. Margin Account & 17 & $0.2 \%$ \\
\hline P. Sweep Account & 290 & $3.6 \%$ \\
\hline Q. Loan/Bank Deposits & 129 & $1.6 \%$ \\
\hline R. Other & 239 & $3.0 \%$ \\
\hline Total & 8,064 & $100 \%$ \\
\hline
\end{tabular}

Some of the above violations were a result of the merger. For instance, audits for Coopers \& Lyband held investments in Price Waterhouse clients. These investments became a violation when the two firms merged. The number of violations as a result of the merger was 3,697. The auditors who held these investments should have disposed of them prior to the merger becoming official (Fardella, Hollander-Blumoff, Fleisher, Fukuyama and Klosterman 2000).

The investigation included a random sample designed to detect unreported violations. Two hundred partners and 200 non-partners were selected as a part of the random sample. As a result of this random sample, it was determined that 155 of the 200 partners selected had at least one unreported violation and 17 of the 200 non-partners had at least one unreported violation. When these results are extrapolated over the entire population, approximately 1,945 to 2,220 partners had at least one unreported violation and approximately 1,838 to 4,184 non-partners had at least one unreported violation. These are significant numbers. A variety of reasons account for the unreported violations such as the following:

- $\quad$ Failure to remember holdings.

- $\quad$ Failure to check independence lists.

- $\quad$ Difficulties in checking the electronic independence lists.

- $\quad$ Lack of knowledge of or access to independence lists.

- $\quad$ Lack of understanding of independence rules and policies.

- $\quad$ Belief that the March 1999 confirmation only asked about present compliance.

- $\quad$ Pressures of client, firm and personal obligations (Fardella, Hollander-Blumoff, Fleisher, Fukuyama and Klosterman 2000). 
As a result of the findings of this report, PriceWaterhouseCoopers has put in place a new independence system. The old system required professionals to only report investments in audit clients. The new system requires them to report all investments whether in clients or not. A computerized system is used to list all audit clients and list all investments held by PWC professionals. When the firm acquires a new audit client, the computerized system generates a disposal notice and mails it directly to all affected professionals. Disciplinary action is taken on professionals who do not comply with the new system. This new system does not relieve professionals from compliance with independence rulings (Fardella, Hollander-Blumoff, Fleisher, Fukuyama, and Klosterman 2000).

\section{Case Study: Arthur Andersen And Enron}

During the 1990s Kenneth L. Lay, Enron's CEO and Chairman, converted Enron from an old economy gas company to a new economy trading company that relied greatly on e-commerce transactions (Lay sold $\$ 100$ million in Enron stock). With a market capitalization of $\$ 67$ billion, 21,000 employees, and $\$ 60$ billion in assets, Enron became the seventh largest company in America and one of the largest companies in the world. It acted as a broker in the natural gas, Internet access, and electricity industries by purchasing and selling energy and bandwidth contacts.

In 2001, Jeff Skilling was hired as the new CEO and resigned from his position after several months (Skilling sold \$66 million in Enron stock). In August 2001, Sherron Watkins wrote Lay a memo stating that Enron was about to implode from a wave of accounting discrepancies. In October 2001, the SEC begins a probe of Enron transactions with its related off shore partnerships. In November 2001, it became known that Enron hid $\$ 5$ billion in liabilities, overstated stockholders equity by $\$ 1.2$ billion, and overstated profits by $\$ 586$ million. The liabilities were buried in partnerships located in various Caribbean countries, such as the Cayman Islands, known for its lax regulations and tax-free environments. The off balance sheet partnerships (Cactus, Raptor, LJM, etc...) were set up by the firm's former chief financial officer, Andrew Fastow who was paid $\$ 30$ million.

As a result, Enron's stock dropped from $\$ 90.00$ per share to $\$ 00.26$ per share in late 2001 with a market capitalization of \$208 million. On December 2, 2001 Enron filed for Chapter 11 bankruptcy protection. The largest bankruptcy in US history was approved in a New York court. Andersen then discloses that they destroyed a significant number of Enron related documents. On January 15, 2002, Andersen fires the lead Enron audit partner, David B. Duncan, from its Houston office. Joseph Berardino was the CEO of Arthur Andersen during the Enron audit. In January 2002, Vice Chairman and Chief Strategic Officer Clifford Baxter committed suicide (Baxter sold \$35 million in Enron stock). On February 15, 2002, Enron officers took the 5th Amendment in front of a Congressional investigation. Enron and Andersen are now under investigation by the SEC, Justice Department, US Labor Department, and Congress.

Below is a list summarizing the problems that occurred during the Enron audit:

- Andersen served as Enron's auditors and management consultants, billing the energy firm over $\$ 50$ million a year.

- $\quad$ There was too cozy a relationship between auditors at Andersen and management at Enron. It clouded Andersen's independence and did not serve the public interest.

- The accounting rules (GAAP) and SEC regulations are not clear enough about the reporting of off balance sheet partnerships.

- $\quad$ Enron's business had changed dramatically, from an old economy gas company to an e-commerce based trading company. However, Andersen failed to adjust its business risk model for Enron.

Kenneth Lay, company officers, and board members were agents working for principles (the stockholders). Accordingly, agents have a fiduciary (legal) responsibility to work on behalf of the principals. Since the purpose of a publicly held company is to maximize the wealth of the shareholders, Enron officers and board members violated the rights of the stockholders and they should be held liable in a court of law. Ken Lay's job was to stay informed: "I didn't know," is not a valid excuse. Accordingly, Andersen is being sued by Enron investors and investigated by the government. 
Auditors should not provide consulting services to audit clients in the future. All assets (including offshore partnerships) and liabilities (including contingent liabilities related to futures contracts, partnership agreements, and leases) under the control of a company must be subjected to rigorous audit procedures. The FASB and the IASC may need to give more guidance in this area. The accounting industry should not be allowed to regulate itself. Accordingly, auditors must be regulated by an independent third party setup by the SEC with the goal of protecting the quality of financial information and normalizing market stability. The SEC must step in and require CPA firms to refocus on the needs of the public interest. In addition, the CEO must not chair the board of directors. The board should hire the auditors to check-up on the CEO. Employees should not be allowed to put $100 \%$ of their retirement savings in one company.

\section{Analysis}

With auditors charged as the professionals who keep public confidence in financial information, independence is the key to maintaining such confidence. A number of the violations in the above investigations were absolutely inexcusable. An auditor under no circumstances should hold a direct or indirect financial interest in a client. To do so, erodes public confidence and reduces the value of the auditor's services. The fact that the majority of the violations were partners is even more of a problem. Partners need to set examples for the entire firm. Their apparent incompetence relating to independence rules caused government officials in the US to oversee a previously selfregulated profession in America.

Other violations of independence rules seem more forgiving. For example, investments in mutual funds or $401 \mathrm{k}$ investments by auditors and their spouses may be easily overlooked when trying to comply with independence rules. In addition, with the fast pace of mergers and acquisitions, an investment that was in compliance with independence rules can suddenly be out of compliance as a result of a merger. Generally, a person invests in a mutual fund within a $401 \mathrm{k}$. This mutual fund manager then invests in hundreds or thousands of investments to diversify risk. Accordingly, most individuals do not closely track all of the investments a mutual fund holds. Therefore, a stock within a mutual fund may not have an influence on the auditor's objectivity.

Independence rules were written many years prior to such complex investing options and certainly could not have foreseen the future. We may be at a crossroads now. If independence rules do not change and auditors are not more careful with their investments, public confidence is sure to erode, causing a certain decrease in the value of their opinions. It is time to review the independence rules, make them realistic to comply with and enhance the auditor's education regarding independence through mandatory continuing professional education.

As a result of the merger between Coopers \& Lybrand and Price Waterhouse, certain violations occurred with respect to investments of some auditors. For instance, an auditor from Price Waterhouse may have had an investment in a Coopers \& Lybrand audit client. When the merger took place between Coopers \& Lybrand and Price Waterhouse, an investment that was acceptable now becomes unacceptable. Although it is easy to see how such a violation could have occurred as a result of the merger, the firms should have taken more precautions to ensure that all partners and non-partners divested such investments on a timely basis prior to the finalization of the merger.

Andersen lost its independence by becoming involved with extensive consulting services for Enron. The Enron case has destabilized the stock market because investors have lost their trust in financial statement information. If the breakdown in the quality of financial information continues, companies will have difficulty raising money through stock and bond offerings and the capitalist system will be damaged. This will have a detrimental effect on the American way of life. Recent settlements over failed audits by Andersen are: $\$ 217$ million to the Baptist Foundation of Arizona, $\$ 75$ million to Waste Management, and $\$ 110$ to Sunbeam shareholders.

The following high-level internal (corporate governance) controls should be maintained by the Board Of Directors (BOD) who are ultimately responsible for the actions and financial stability of the organizations they direct: 
- $\quad$ The officers of the company should not be allowed to sit on the BOD.

- $\quad$ The BOD should be elected by the shareholders or other outside parties (e.g.: major donors of a not-forprofit organization) and not appointed by the officers.

- $\quad$ The outside auditing firm should be hired by and report directly to the BOD.

- $\quad$ The BOD should meet frequently, stay informed, review the long-term strategic plan, and approve all major and financially material expenditures.

- $\quad$ The BOD should hire and review all high-level officers (CEO, CIO, CFO, COO, etc...) of the organization.

- $\quad$ The officers must present and explain the audited financial statements to the BOD on a regular basis (usually four times per year).

- When a company materially changes its business model, such as creating an e-commerce division, the auditors must be briefed by the BOD. This will allow the auditors to adjust their estimate of business risk.

As a result of the problems with Andersen and PWC, the US government has started to regulate the accounting industry in the US. President Bush signed into law the Sarbanes-Oxley Act of 2002. The Act includes farreaching changes in federal securities regulation that represents the most significant overhaul since the enactment of the Securities Exchange Act of 1934. The Act prescribes a system of federal oversight of public auditors through a Public Company Accounting Oversight Board, a new set of auditor independence rules, new disclosure requirements applicable to public companies, and new penalties for persons who are responsible for accounting or reporting violations (Cary 2002). The Act also imposes restrictions on loans and stock transactions involving corporate officers and insiders. Summary of the Sarbanes-Oxley Act of 2002 is listed below (AICPA 2002):

- Increases criminal penalties for corporate crimes up to 20-year prison terms and fines of $\$ 1$ to $\$ 5$ million.

- $\quad$ Creates a review board to police the accounting industry.

- $\quad$ Prevents accountants from auditing and consulting with the same corporation.

- $\quad$ Require top executives to vouch for their firm's financial statements.

- $\quad \$ 300$ million will go to the SEC to hire 200 investigators and auditors.

- $\quad$ Bans personal loans from companies to their officers and directors.

- $\quad$ Gives the SEC authority to ban corporate wrong-doers from serving as company officers in the future.

- $\quad$ Prohibits officers from filing bankruptcy to avoid paying financial judgments.

\section{Conclusion}

Independence is the most important factor in determining an auditor's objectivity with regards to an audit client. Noncompliance with independence rules erodes public confidence and reduces the value of the auditor's services. Such an erosion of public confidence could result in deterioration in the efficiencies of capital markets. In addition, if the public has no confidence in the accounting industry, the government may intervene with selfregulated professions as it has done with the Sarbanes-Oxley in America. Such government intervention is generally undesirable. The Institute of Chartered Accountants has avoided government regulation.

With such an undesirable outcome of the special investigation of PriceWaterhouseCoopers, the public and the profession are left to wonder about the independence of the other large firms. These large firms conduct the majority of the publicly traded companies in the United States. If the independence problems are as widespread as they were at PWC and Andersen, the efficiency of the worldwide capital markets is at risk. A profession that has avoided extensive government regulation is striving to avoid more intervention. The accounting profession must restore the public's confidence that auditors are independent in fact and appearance when performing attestation services.

The SEC Practice Section of the AICPA did create new independence rules that became effective in January 2000 that required CPAs to establish formal independence policies covering certain relationships, including financial interests, business relationships and employment. They also are requiring independence trainings and the maintenance of a database for each member of the firm that includes those members' investments. This database should aid in independence compliance. 
In addition, The Independence Standards Board (ISB) proposed a new ruling that addressed investments in audit client mutual funds. This new standard would allow spouses and dependents of other partners to invest in mutual funds that are audit clients. It does specifically exclude any professional who participates on the engagement. Such a new ruling would eliminate some of the violations found at PriceWaterhouseCoopers.

Rulings, such as those discussed in the previous paragraph, are needed to ease the ability to maintain compliance of independence. Such rulings do not appear to undermine investor confidence in auditors. With the work of the SEC Practice Section of the AICPA and the Independence Standards Board, public confidence may be restored. Moreover, a self-regulated accounting profession will continue to serve the public with the utmost integrity as it has in Canada and Europe.

The managers, owners, and board members at e-commerce companies should make sure they aren't left in the dark by staying informed and hiring independent auditors. Most auditors are very honest and hard-working individuals. We should not let the actions of a few dishonest individuals damage the whole auditing profession. Thousands of organizations are satisfied with their auditors and auditors are necessary to maintain international capital markets.

\section{References}

1. $\quad$ AICPA (2002). "Summary of Sarbanes-Oxley Act". www.aicpa.org.

2. Arens, A. A. and J. K. Loebbecke (1988). Auditing: An Integrated Approach, 4th edition. Englewood Cliffs, New Jersey: Prentice Hall, Inc.

3. Arnold, V. and S. G. Sutton (2002). Researching Accounting as an Information Systems Discipline. American Accounting Association, Sarasota, Florida.

4. $\quad$ Burke, J. F. (1998). "The SEC Comments On White Paper". The CPA Journal, March.

5. Cary, G. (2002). "President Signs Sarbanes-Oxley Act of 2002". www.gcwf.com.

6. Carmichael, D. R. (1998), “A Conceptual Framework for Independence”. The CPA Journal, March.

7. Carmichael, D. (1999), "In Search of Concepts of Auditor Independence". The CPA Journal, May.

8. Clikeman, P. M. (1998). "Auditor Independence: Continuing Controversy". Ohio CPA Journal, AprilJune.

9. Craig, J. L. (1999). “The CPA and Independence: Illusion or Reality?” The CPA Journal, March.

10. Deitel, H. M., P. J. Deitel and K. Steinbuhler (2001). E-Business and E-Commerce for Managers. Prentice Hall, Upper Saddle River, NJ.

11. Ellis, L. (2000). "Mergers \& Acquisitions Raise Ethical Questions. Ethics Releases Address Independence". The CPA Journal, February.

12. Fardella, J., R. Hollander-Blumoff, B. Fleisher, R. Fukuyama, and A. Klosterman (2000). Report of the Internal Investigation of Independence Issues At PriceWaterhouseCoopers LLP. U.S. Securities and Exchange Commission, AP File No. 3-9809, January 6.

13. Goldwasser, D. L. (1999). "Is it possible to achieve? Independence in a Changing Accounting Profession". The CPA Journal, October.

14. Greenberg, H. (1998). "The Auditors Are Always Last to Know". Fortune, August 17.

15. Huefner, R. J. (1998). "The Future of Non-CPA Ownership". The CPA Journal, February.

16. Kinney, W. R. (1999). “Auditor Independence: A burdensome Constraint or Core Value?" Accounting Horizons, March.

17. Knechel, R. W. (1998). Auditing: Text \& Cases. South-Western College Publishing, Cincinnati, Ohio.

18. Lee, C. J. and Z. Gu (1998). "Low Balling, Legal Liability and Auditor Independence". The Accounting Review, October.

19. Levitt, A. (1999). Quality Information: The Lifeblood of Our Markets. Securities Exchange Commission Speech, October 18, Washington D. C. Available at www.sec.gov.

20. Mac Donald, E. (2000). “Accountant Faces Salvo From SEC”. Wall Street Journal, February 28.

21. MacDonald, E. and M. Schroeder (2000). "Report by SEC Says PriceWaterhouse Violates Rules on Conflicts of Interest". Wall Street Journal, January 7. 
22. MacDonald, E. (2000). "PriceWaterhouseCoopers Will Divide Into Two or More Parts, Under Pressure". Wall Street Journal, February 18.

23. Revsine, L., D. W. Collins and W. B. Johnson (1999). Financial Reporting and Analysis. Prentice Hall, Upper Saddle River, NJ.

24. Schroeder, R. G. and M. W. Clark (1998). Accounting Theory: Text and Readings, Sixth Edition. John Wiley \& Sons, New York, NY.

25. Stevens, M. G. (1997). "Independence of Public Auditors Being Questioned". The Practical Accountant, July.

26. Walker, R. H. (1999). "The SEC Director of Enforcement addresses the importance of being independent. Auditor Independence: The Issues". The CPA Journal, May.

27. Ward, G. M. (1998). "The Big-Five Battle: CPAs and non-CPAs Square Off On Auditor Independence". Financial Executive, July/August.

28. Webmergers (2002). "Dot Com Failures Down 73\% from 2001 Levels in First Half”. www.webmergers.com.

29. Whittington, O. R. and K. Pany (1998). Principles of Auditing, 12th edition. Irwin McGraw-Hill, Boston, Massachusetts.

30. Wolk, H. I., M. G. Tearney and J. L. Dodd (2001). Accounting Theory: A Conceptual and Institutional Approach, fifth edition. Southern-Western College Publishing, Cincinnati, Ohio.

31. Zhang, P. (1999). "A Bargaining Model of Auditor Reporting”. Contemporary Accounting Research, Spring. 